\title{
Meso-scale spatial variation in bacterial abundance and production associated with surface convergence and divergence in the NE equatorial Pacific
}

\author{
Jung-Ho Hyun*, Eun Jin Yang
}

Marine Biotechnology Research Center, Korea Ocean Research \& Development Institute, Ansan PO Box 29, Seoul 425-600, ROK

\begin{abstract}
To elucidate the effect of the water column structure associated with surface water convergence and divergence on bacterial parameters, we investigated the meso-scale spatial variations in bacterial abundance and production in the northeast equatorial Pacific from 5 to $12^{\circ} \mathrm{N}$ (longitude $131^{\circ} 30^{\prime} \mathrm{W}$ ). The area is characterized by 3 major surface currents: the South Equatorial Current (SEC), North Equatorial Counter Current (NECC), and North Equatorial Current (NEC). Surface water convergence occurred at the boundary of the westward-flowing SEC and eastwardflowing NECC, and divergence occurred at the boundary of the NECC and westward NEC. A vertically well-mixed water column observed in the SEC/NECC area appeared to be high in nutrients and chlorophyll a $(\mathrm{chl}$ a), whereas the strongly stratified NEC area had a relatively low trophic status, with a surface layer depleted of nitrates and chl a. Accordingly, bacterial abundance, production, and mean biomass turnover rates, as well as grazing by heterotrophic nanoflagellates (HNF) in the wellmixed SEC/NECC area were consistently higher than in the highly stratified NEC area. The greater bacterial production and HNF grazing in the SEC/NECC region imply that heterotrophic bacteria are a significant trophic link between dissolved organic carbon and higher trophic levels in the microbial loop of the SEC/NECC area. Our results indicate that changes in the water column structure in relation to convergence and divergence play a key role in enhancing the amount of nutrients and chl $a$, thereby stimulating bacterial abundance and production and intensifying the trophic link between heterotrophic bacteria and heterotrophic protists in the microbial food web in the study area.
\end{abstract}

KEY WORDS: Bacterial production - Convergence - Divergence - Meso-scale spatial variations · Northeast equatorial Pacific

\section{INTRODUCTION}

Heterotrophic bacteria play a significant role in the biogeochemical carbon cycle and the microbial food web. Bacteria are responsible for the rapid turnover of dissolved organic matter from various sources (Kirchman et al. 1991, Nagata 2000). Bacterial biomass in the oligotrophic open ocean is substantial among planktonic communities (Fuhrman et al. 1989, Cho \& Azam 1990, Li et al. 1992, Caron et al. 1995), implying that bacteria are a major carbon-sequestering planktonic component in the open ocean. In the microbial food web, heterotrophic bacteria also serve as a significant trophic link between dissolved organic carbon (DOC) and heterotrophic nanoprotists (HNP) and small ciliates, which are then consumed by metazoan microzooplankton (Azam et al. 1983, Sherr et al. 1986).

Bacterial abundance and production, as well as the relative significance of bacterioplankton in the biogeochemical carbon cycle and microbial food web, are largely affected by water column structures that control the physical stability and nutrient conditions within a water mass (Holligan et al. 1984, Ducklow 1986, Kiørboe et al. 1990, Hyun \& Kim 2003). Other 
studies have also recognized that the HNP grazing that regulates bacterial biomass and production, and thereby determines the ecological role of bacteria in microbial food web processes, varied with the trophic, i.e. nutritional, conditions of water columns (Dufour \& Torréton 1986, Sanders et al. 1992, Ducklow 2000). Therefore, a thorough interpretation of variations in bacterial abundance and production requires a comprehensive understanding of the water column structures controlling the physico-chemical properties of water masses.

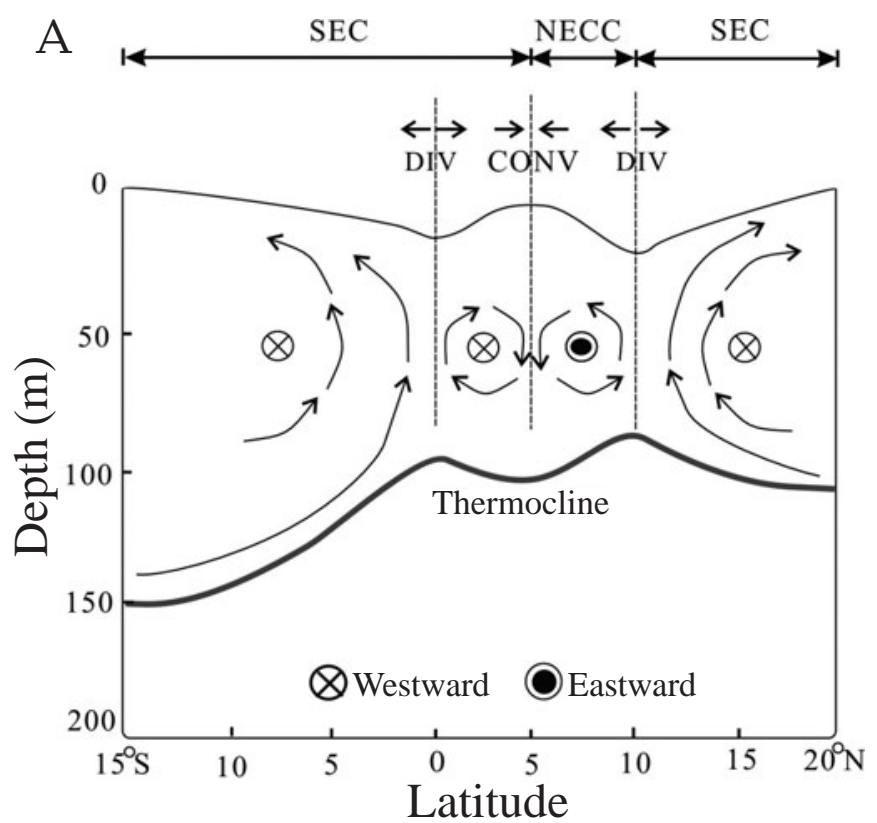

B

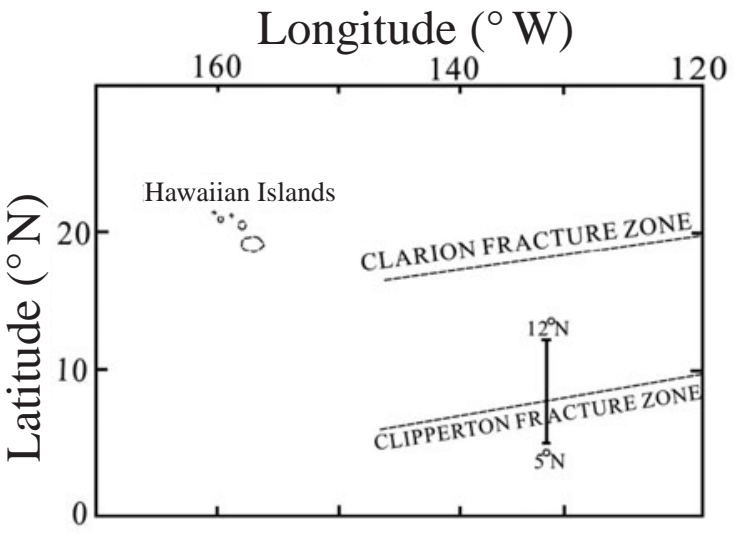

Fig. 1. (A) Schematic presentation of the surface current system in the equatorial Pacific and (B) a map showing the study area. SEC: westward-flowing South Equatorial Current; NECC: eastward-flowing North Equatorial Counter Current; NEC: westward-flowing North Equatorial Current. Surface divergence (DIV) occurs along the equator and at the boundary of the NECC and NEC, whereas surface water convergence (CONV) occurs at the boundary of the SEC and NECC
The surface waters of the northeast equatorial Pacific $\left(5\right.$ to $\left.20^{\circ} \mathrm{N}\right)$ are influenced by 3 major currents (Pickard \& Emery 1982; Fig. 1A): the westward-flowing North Equatorial Current (NEC), the eastwardflowing North Equatorial Counter Current (NECC), and the westward-flowing South Equatorial Current (SEC). The Coriolis effect deflects the westward NEC and SEC to the north and the eastward NECC to the south. Regional surface water divergence (DIV) occurs along the boundary of the NEC and NECC, whereas surface water convergence (CONV) occurs along the boundary of the SEC and NECC. The water column structures of the DIV area are characterized by relatively lower sea level and shallower thermocline depths compared to the surrounding water masses, whereas the CONV area has a higher sea level and a deeper thermocline (Pickard \& Emery 1982; Fig. 1A). The CONV and DIV events disrupt the vertical stability of the water column and add nutrient-rich subsurface waters to the nutrient-depleted surface mixed layer, thereby enhancing biological productivity (Mann \& Lazier 1991) and trophic interaction between prey and predator organisms (Barange et al. 1998, Bradford-Grieve et al. 1998, James \& Hall 1998).

A substantial amount of information on the spatial and temporal variations in bacterial abundance and production and the potentially limiting resources controlling bacterial production in the equatorial Pacific has been accumulated during the US JGOFS Process Study in the Equatorial Pacific (EqPac) Program (Ducklow et al. 1995, Kirchman et al. 1995, Chung et al. 1996, Landry et al. 1996, Rich et al. 1996, Landry \& Kirchman 2002). To our knowledge, however, relatively few studies have focused on the meridional meso-scale spatial variation in the properties of bacteria and protozoans and the significance of the trophic linkage between bacteria and heterotrophic protists in association with water column structure in the northeast equatorial Pacific (5 to $12^{\circ} \mathrm{N}$ ), where 3 dynamic surface currents control the physico-chemical parameters (Hyun et al. 1998, Yang et al. 2004). Thus, the objective of this study was to elucidate the spatial variations in bacterial abundance, production, and biomass turnover rates in relation to surface water CONV/DIV in the northeast equatorial Pacific. Based on the higher bacterial abundance and production together with the higher protozoan biomass and grazing impact in the well-mixed CONV/DIV area, we also discussed how variations in the water column structures were responsible for regulating the intensity of the trophic link between bacterioplankton and HNP in the microbial food web process. 


\section{MATERIALS AND METHODS}

Study area. The study area is considered to be a transition zone between the classic high-nitrate, lowchlorophyll a (HNLC) equatorial Pacific and the oligotrophic, subtropical north Pacific gyre (SNPG) found from 15 to $35^{\circ} \mathrm{N}$ (Murray et al. 1995, Karl 1999). The nitrate concentration in the surface mixed layer $(<1 \mu \mathrm{M})$ is therefore lower than in the classic HNLC environment, but higher than in the oligotrophic SNPG characterized by nitrate concentrations of $<5 \mathrm{nM}$ (Karl 1999). As a part of the Korea Deep Ocean Study program in 1998 (KODOS-98), we conducted water sampling at every $1^{\circ}$ of latitude between 5 and $12^{\circ} \mathrm{N}$ (longitude $131.5^{\circ} \mathrm{W}$ ) in the northeast equatorial Pacific (Fig. 1B), where interactions between 3 surface currents, the SEC, NECC, and NEC, largely determine the physico-chemical and microbiological parameters.

Environmental parameters. Water temperature and salinity were measured using a CTD meter (SBE 911 Plus, Seabird Electronics). Seawater samples were collected for chemical and microbiological analyses using Niskin bottles attached to a rosette sampler. Sampling bottles were first washed with $10 \% \mathrm{HCl}$ and rinsed with Milli-Q water and surface seawater. Samples for the nitrate analysis were collected using acid-washed polyethylene bottles and stored at $-20^{\circ} \mathrm{C}$ until they were processed. Nitrate was analyzed according to Parsons et al. (1984). Following acetone extraction, chlorophyll a ( $\mathrm{chl}$ a) concentrations were measured using a spectrophotometer (Parsons et al. 1984). In addition, in situ chl a fluorescence was measured using an underwater fluorometer (SeaTech) to depict the vertically continuous distributions of chl $a$. The chl a concentrations were then calculated from the linear relationship between the in situ fluorescence (flu) and the spectrophotometrically measured concentrations of chl $a$ with the following equation: $\mathrm{chl} a=0.2944 \times$ flu $0.2745, \mathrm{r}^{2}=0.83, \mathrm{n}=101$. Phytoplankton carbon biomass was estimated according to Caron et al. (1995) using a C:chl a ratio of 60 for depths of 0 to $30 \mathrm{~m}$, a ratio of 40 for depths between 30 and $60 \mathrm{~m}$, and a ratio of 30 for depths below $60 \mathrm{~m}$.

Bacterial abundance and production. Water samples for bacterial cell counts were preserved with glutaraldehyde (final concentration 1\%) and stored at $-20^{\circ} \mathrm{C}$ until they were processed (Hyun \& Yang 2003). Samples were stained with 4',6-diamidino-2-phenylindole (DAPI; Porter \& Feig 1980), filtered through Nuclepore filters $(0.2 \mu \mathrm{m}$ pore size, black), and mounted on slides with immersion oil (Cargille Type A). The bacteria were counted using an epifluorescence microscope (Zeiss Axioskop) equipped with a mercury lamp (HB-10101 AF), an ultraviolet (UV) excitation filter, and a BA 420 barrier filter. At least
20 microscopic fields were examined. Bacterial carbon biomass (BCB) was estimated from bacterial cell counts using a conversion factor of $12 \mathrm{fg} \mathrm{C}$ cell $^{-1}$ (Fukuda et al. 1998).

The heterotrophic bacterial production was estimated from the incorporation rate of ${ }^{3} \mathrm{H}$-thymidine $\left({ }^{3} \mathrm{H}-\mathrm{TdR}\right.$; Fuhrman \& Azam 1980, 1982). Duplicate $20 \mathrm{ml}$ water samples were incubated with ${ }^{3} \mathrm{H}-\mathrm{TdR}$ (final concentration $5 \mathrm{nM}$ thymidine, New England Nuclear, NET 027X) at in situ water temperature for $30 \mathrm{~min}$ in disposable plastic centrifuge tubes. The samples were poured into $50 \%$ ice-cold trichloroacetic acid (TCA) solution (final concentration $5 \%$ ), and TCA-insoluble macromolecules were extracted in an ice bath for $15 \mathrm{~min}$. The samples were collected by vacuum filtration on $0.2 \mu \mathrm{m}$ cellulose nitrate membrane filters (MFS) and rinsed 3 times with ice-cold $80 \%$ ethanol. The filters were placed in scintillation vials with $10 \mathrm{ml}$ of scintillation cocktail (Lumagel Safe, Lumac-LSC), and the radioactivities of the TCAinsoluble macromolecules were determined using a liquid scintillation counter (LKB, RackBeta II). Samples treated with $10 \%$ TCA before the addition of ${ }^{3} \mathrm{H}$-TdR were used as controls. To convert TdR measurements into bacterial cell production, the conversion factor of

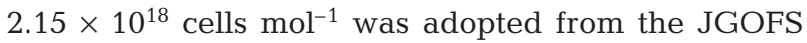
EqPac studies (Kirchman et al. 1995).

Substrate-enriched incubation experiment. To elucidate the effect of substrate enrichment on bacterial production in the SEC/NECC and NEC regions, timecourse incubation experiments were designed. Surface water samples were collected at depths of $30 \mathrm{~m}$ at $5^{\circ} \mathrm{N}$ (i.e. CONV area) in the vertically well-mixed SEC/ NECC area characterized by relatively high nutrient and chl a concentrations and at $10^{\circ} \mathrm{N}$ in the highly stratified NEC area with low nutrient and chl a concentrations. The seawater samples were first filtered through pre-combusted $\left(400^{\circ} \mathrm{C}\right) \mathrm{GF} / \mathrm{F}$ filters and then mixed with ambient seawater $(9: 1 ; \mathrm{v} / \mathrm{v})$ to minimize the grazing impact on bacterial abundance (Kirchman et al. 1991). The water samples were distributed into 21 acidwashed polycarbonate bottles and manipulated with $2 \mathrm{ml}$ of the plankton extract dissolved substrates (PEDS). The water samples were then incubated in the dark at in situ temperature by circulating in ambient surface seawater. Subsamples for bacterial cell counts were collected over time. The PEDS were obtained following modified methods of Cherrier et al. (1996). Natural phytoplankton and zooplankton assemblages were collected using plankton nets with a mesh size of 58 and $300 \mu \mathrm{m}$, respectively. The plankton samples were mixed together, placed in an incubator at $40^{\circ} \mathrm{C}$ for $2 \mathrm{~h}$ to accumulate extracellular metabolic products, and then filtered through pre-combusted $\left(400^{\circ} \mathrm{C}\right) \mathrm{GF} / \mathrm{F}$ filters to remove plankton and other particles. These PEDS contain various labile substrates, such as amino 


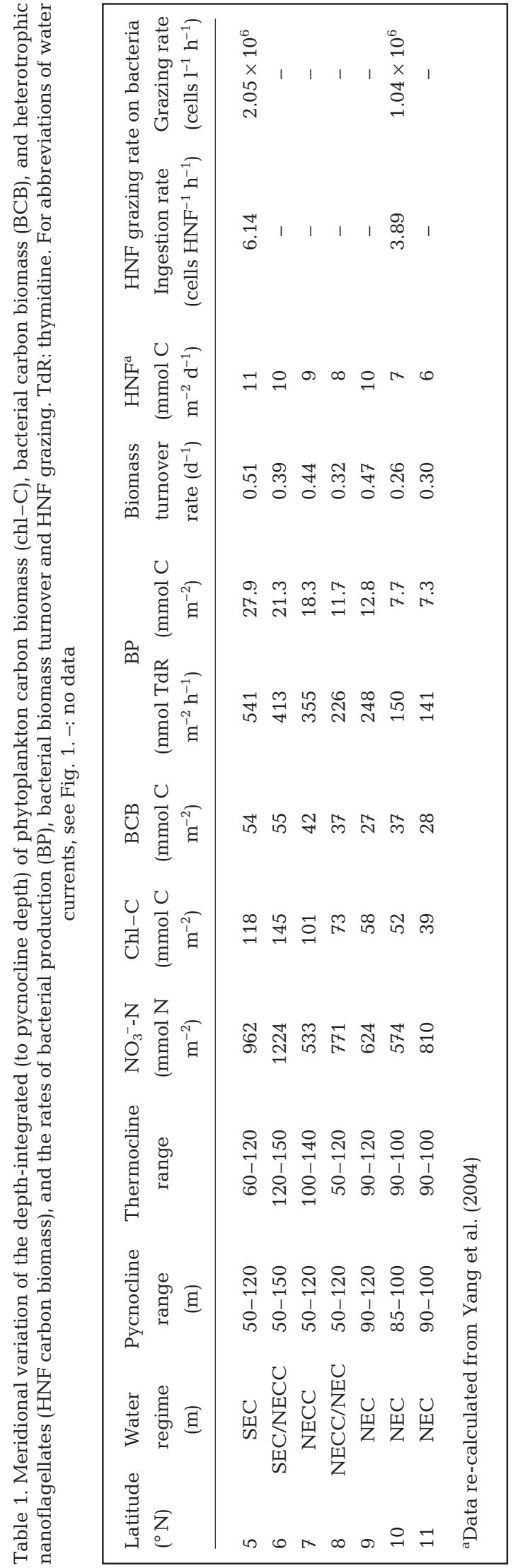

acids, carbohydrates, and ammonium, that stimulate bacterial growth (Münster \& Chróst 1990, Sundh 1992, Cherrier et al. 1996, Strom et al. 1997, Nagata 2000).

Grazing by HNF. HNFs ( 2 to $5 \mu \mathrm{m}$ in size) were chosen for bacteria ingestion experiments, as they were likely the principle predators of bacteria in the oligotrophic open ocean (Calbet \& Landry 1999). Observations of HNF grazing on bacteria were made using fluorescently labeled bacteria (FLB). The FLB were prepared by staining natural bacteria samples collected 3 to $4 \mathrm{~d}$ before the experiments. Natural bacteria were concentrated on $0.2 \mu \mathrm{m}$ filters following the pre-filtration of 21 of seawater through $0.7 \mu \mathrm{m}$ filters to remove larger size autotrophic picoplankton such as Prochlorococcus $(0.5$ to $2.0 \mu \mathrm{m})$ and Synechococcus (1.0 to $2.0 \mu \mathrm{m})$ (Table 1 in Sherr \& Sherr 2000). As the concentration of cells by centrifugation can cause significant losses of small bacterial cells and thereby alter the original size distribution (Sherr et al. 1987), the concentrated bacteria cells were heat-killed and stained with 5-(4,6-dichlorotriazin-2yl) aminofluorescein (DTAF), following the methods of Sherr et al. (1987). Water samples for the grazing experiments were collected at a depth of $30 \mathrm{~m}$ at 5 and $10^{\circ} \mathrm{N}$ and gently filtered through a $200 \mu \mathrm{m}$ mesh. The FLB uptake experiments were carried out in duplicate in $300 \mathrm{ml}$ bottles presoaked in $10 \% \mathrm{HCl}$ and rinsed well with Milli-Q water. FLB stock (1 or $2 \mathrm{ml}$ ) with 7 to $10 \%$ bacterial abundance was added to the $300 \mathrm{ml}$ bottles. The grazing experiment was conducted in the dark at in situ temperature. Subsamples of $40 \mathrm{ml}$ were taken from each bottle at 0,10 , $20,30,45$, and $60 \mathrm{~min}$, preserved with a mixture of alkaline Lugol solution and borate-buffered formalin (Sherr et al. 1989), and kept refrigerated until they were examined microscopically. The subsamples were stained with DAPI (final concentration $10 \mu \mathrm{g} \mathrm{ml}^{-1}$ ) and filtered onto $0.8 \mu \mathrm{m}$ polycarbonate filters (black, $25 \mathrm{~mm}$ diameter); the filters were mounted for immediate epifluorescence microscopy. The filters were first observed under UV light at a magnification of $\times 1000$, and, when an HNF was located, the incident light was changed to blue light, which allowed for the counting of FLB inside the HNF. The number of ingested FLB $\mathrm{HNF}^{-1} \mathrm{~h}^{-1}$ (FLB uptake rate) was calculated from the slope of ingested FLB $\mathrm{HNF}^{-1}$ versus incubation time for each bottle. We calculated grazing rates on heterotrophic bacteria (cells $\mathrm{l}^{-1} \mathrm{~h}^{-1}$ ) and ingestion rates (cells $\mathrm{HNF}^{-1} \mathrm{~h}^{-1}$ ), as described by Cho et al. (2000). The coefficients of variation of the slopes from duplicate bottles were $4.7 \%$ at $5^{\circ} \mathrm{N}$ and $6.4 \%$ at $10^{\circ} \mathrm{N}$.

Data analysis. The surface layers were defined based on the bottom of the pycnocline, which generally coincided with the thermocline, nitracline, and euphotic depth, i.e. approximately 100 to $150 \mathrm{~m}$ (Table 1, Figs. 2 \& 3). Area-based inventories of nitrate, 
chl $a$, and bacterial biomass and production were obtained from the integration of volume-based values at depths down to the bottom of the surface layer, i.e. the bottom of the pycnocline layer. The mean bacterial biomass turnover rates, equivalent to the mean bacterial growth rates, were estimated by dividing the depthintegrated bacterial production by the integrated bacterial biomass (Kirchman et al. 1995).

\section{RESULTS}

\section{Hydrographic conditions}

The water temperature and salinity ranged from 11.20 to $28.51^{\circ} \mathrm{C}$ and from 33.81 to $35.02 \mathrm{psu}$, respectively. The vertical profiles of water temperature, salinity, and density (Fig. 2) indicated that water temperature was the major factor determining water column density in the study area. The most pronounced physical features that appeared in the upper 200 m were: (1) a weak, broad, seasonal thermocline between 5 and $8^{\circ} \mathrm{N}$ and (2) a highly stratified water column with a sharp thermocline between 9 and $12^{\circ} \mathrm{N}$. A weak seasonal thermocline within $200 \mathrm{~m}$ depth in the stations located from 5 to $8^{\circ} \mathrm{N}$ suggested that the water mass was vertically well mixed. This vertical mixing was associated with a surface water convergence resulting from the shear between the westwardflowing SEC and the eastward-flowing NECC (Johnson 1996, Archer et al. 1997). The deepest thermocline (approximately $150 \mathrm{~m}$ ) appeared at $6^{\circ} \mathrm{N}$, where $\mathrm{CONV}$ occurred at the boundary of SEC and NECC. On the other hand, DIV resulted in a shallow seasonal thermocline at $8^{\circ} \mathrm{N}$, where the westward-flowing NECC meets the eastward-flowing NEC (Pickard \& Emery 1982). The vertical profiles of water temperature and density in the study area in July 1998 indicated that the water columns could be divided into 2 categories: a well-mixed water mass resulting from surface water convergence between 5 and $7^{\circ} \mathrm{N}$ (SEC/NECC area) and a highly stratified water column between 9 and $12^{\circ} \mathrm{N}$ (NEC area; Fig. 2).

\section{Nitrate and chl a}

$\mathrm{NO}_{3}{ }^{-}$levels in the surface waters of the stratified NEC area were depleted by biological uptake and by the deep seasonal thermocline, which ultimately blocks the supply of limiting nutrients from below (Fig. 3). In contrast, a relative abundance of $\mathrm{NO}_{3}{ }^{-}$was
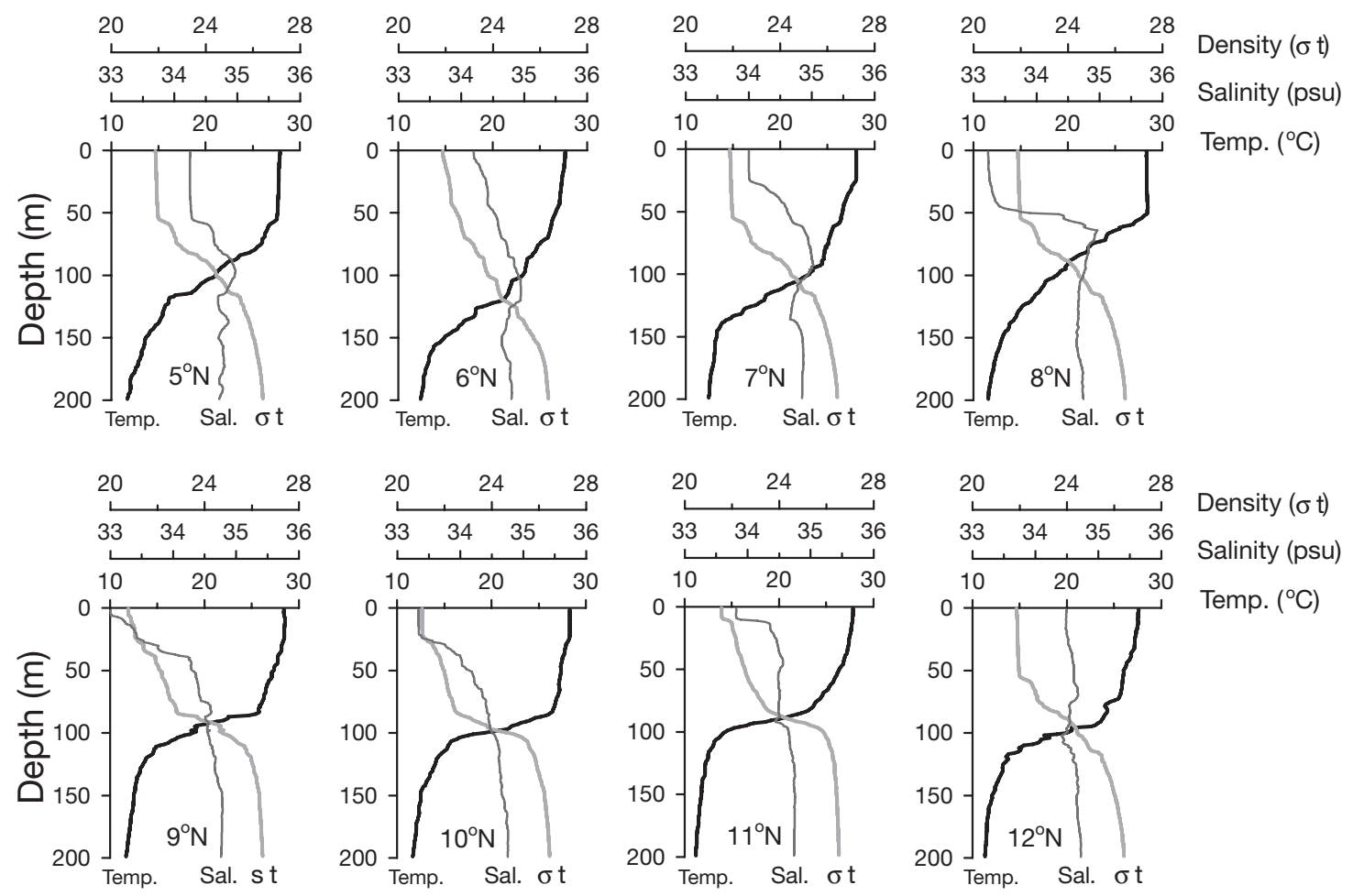

Fig. 2. Vertical distributions of temperature, salinity, and density. Surface water convergence is evident from the weak vertical density gradient in the SEC/NECC area from 5 to $7^{\circ} \mathrm{N}$, whereas the NEC area is characterized by a strong vertical density gradient from 9 to $12^{\circ} \mathrm{N}$. A divergence center with a shallow thermocline depth appears at $8^{\circ} \mathrm{N}$ 

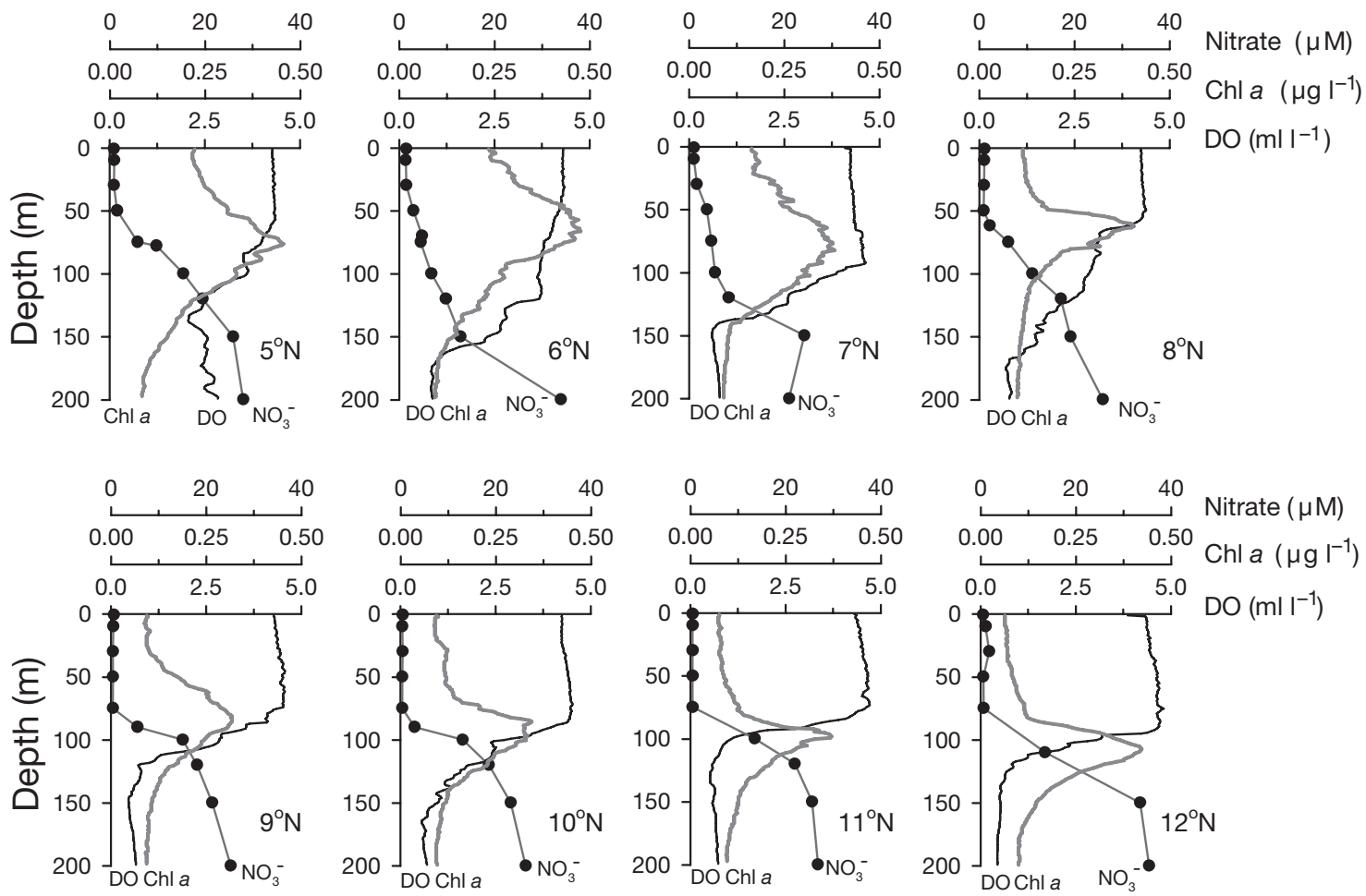

Fig. 3. Vertical distributions of nitrate $\left(\mathrm{NO}_{3}{ }^{-}\right)$, chlorophyll a (chl a), and dissolved oxygen (DO)

observed in the well-mixed SEC/NECC area. The northern part of the study area $\left(9\right.$ to $\left.12^{\circ} \mathrm{N}\right)$ had nitrate concentrations $<1 \mu \mathrm{M}$, somewhat different from the typical HNLC environment of the equatorial Pacific (Murray et al. 1995). Inventories of $\mathrm{NO}_{3}^{-}$integrated down to the surface layer depth ranged from 574 to $1224 \mathrm{~mol} \mathrm{~N} \mathrm{~m}^{-2}$ (mean: $785 \mathrm{~mol} \mathrm{~N} \mathrm{~m}^{-2}$ ). Inventories of $\mathrm{NO}_{3}{ }^{-}$at the well-mixed SEC/NECC area (mean: $906 \mathrm{~mol} \mathrm{~N} \mathrm{~m}^{-2}$ ) were higher than at the highly stratified NEC area (mean: $669 \mathrm{~mol} \mathrm{~N} \mathrm{~m}^{-2}$; Table 1).

Concentrations of chl a ranged from 0.09 to $0.48 \mu \mathrm{gl}^{-1}$ and appeared to be influenced by the physico-chemical conditions of the water column (Fig. 3). Depth-integrated phytoplankton carbon biomass (chl-C) ranged from 39 to $145 \mathrm{mmol} \mathrm{C} \mathrm{m}^{-2}$ (mean: $83.7 \mathrm{mmol} \mathrm{C} \mathrm{m}^{-2}$ ). $\mathrm{Chl}-\mathrm{C}$ in the well-mixed SEC/NECC area was higher (mean: $121.3 \mathrm{mmol} \mathrm{C} \mathrm{m}^{-2}$ ) than in the highly stratified NEC area (mean: $49.7 \mathrm{mmol} \mathrm{C} \mathrm{m}^{-2}$; Table 1), which was associated with the relative abundance of nutrients supplied through the weak seasonal thermocline (Figs. 2 \& 3). The subsurface chl a maximum (SCM) layer, which forms at depths where both light and nutrient conditions are suitable for phytoplankton growth, generally occurred at the thermocline depth. The SCM layers in the NEC stations were observed at depths between 90 and $110 \mathrm{~m}$, with a sharp vertical gradient in chl a concentrations, while the SCM layers in the mixed stations appeared to be broader, in agreement with the broad formation of the seasonal thermocline and nitracline (Figs. 2 \& 3). Overall, the distribution of physicochemical and biological parameters was closely associated with water column structures. The mixed SEC/NECC area appeared to be high in nutrients and chl $a$, whereas the strongly stratified NEC area showed relatively lower trophic status, with a surface layer deplete of nitrates and chl a (Fig. 3).

\section{Bacterial abundance and production}

The bacterial cell numbers in the surface water columns ranged from $4.20 \times 10^{7}$ to $6.26 \times 10^{8}$ cells l$^{-1}$

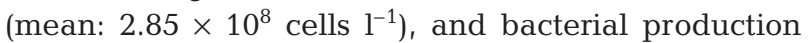
ranged from 0.14 to $4.89 \mathrm{pM} \mathrm{TdR} \mathrm{h}^{-1}$ (mean: $1.95 \mathrm{pM}$ $\mathrm{TdR} \mathrm{h}^{-1}$; Fig. 4). The distribution of bacterial abundance and production appeared to be controlled by the physico-chemical properties in the water column (Figs. 2 \& 3), with higher values in the well-mixed SEC/NECC area. Depth-integrated BCB within the surface layer ranged from 27 to $55 \mathrm{mmol} \mathrm{C} \mathrm{m}^{-2}$ (mean: $40.0 \mathrm{mmol} \mathrm{C} \mathrm{m}{ }^{-2}$; Table 1). Bacterial biomass in the well-mixed SEC/NECC region (mean: $50.3 \mathrm{mmol} \mathrm{C}$ $\mathrm{m}^{-2}$ ) was higher than that in the stratified NEC region (mean: $30.7 \mathrm{mmol} \mathrm{C} \mathrm{m}^{-2}$ ). 

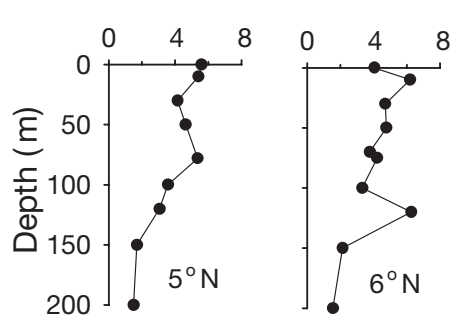

Bacterial cell number ((cells I-1) $\left.\times 10^{8}\right)$
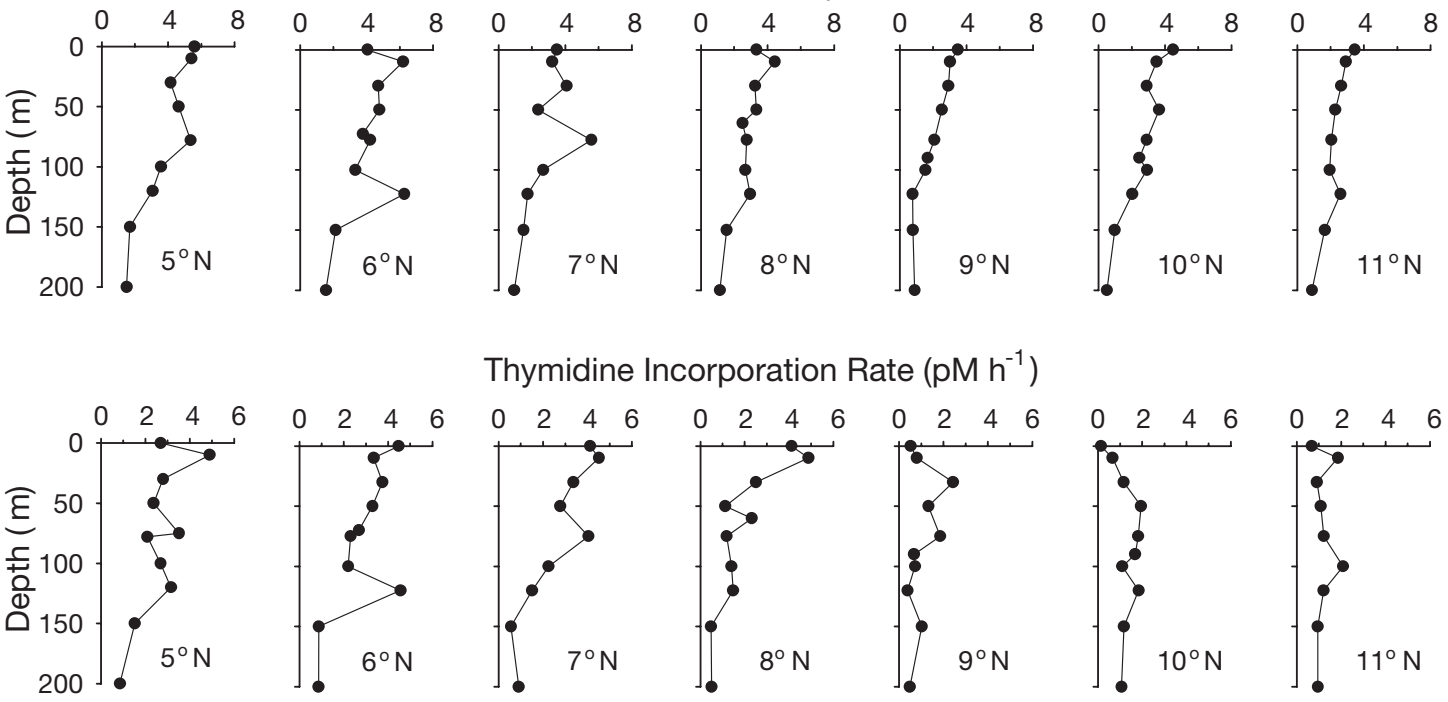

Thymidine Incorporation Rate $\left(\mathrm{pM} \mathrm{h}^{-1}\right)$
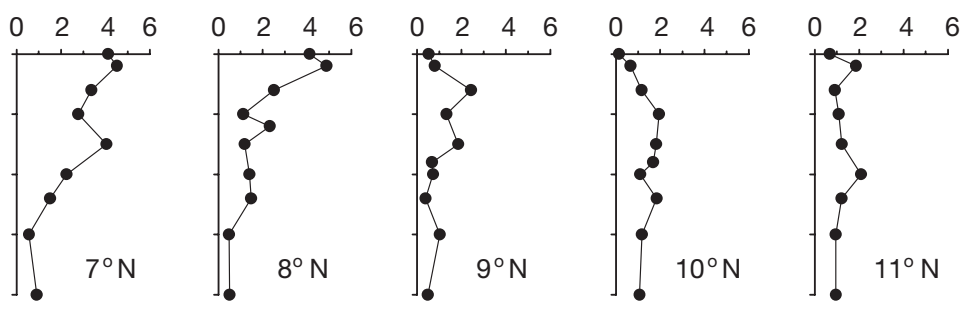

Fig. 4. Vertical distributions of total prokaryotic cell number and heterotrophic bacterial production

Depth-integrated bacterial production ranged from 141 to $541 \mathrm{nmol} \mathrm{TdR} \mathrm{m}^{-2} \mathrm{~h}^{-1}$ (mean: $296 \mathrm{nmol} \mathrm{TdR} \mathrm{m}^{-2}$ $\mathrm{h}^{-1}$ ), and was also higher in the SEC/NECC region

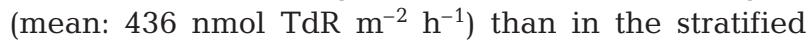
NEC region (mean: $180 \mathrm{nmol} \mathrm{TdR} \mathrm{m}^{-2} \mathrm{~h}^{-1}$ ). The bacterial biomass turnover rates, estimated by dividing bacterial production by bacterial biomass, ranged from 0.26 to $0.51 \mathrm{~d}^{-1}$ (mean: $0.38 \mathrm{~d}^{-1}$ ), and were higher in the SEC/NECC region (mean: $0.45 \mathrm{~d}^{-1}$ ) than in the stratified NEC region (mean: $0.34 \mathrm{~d}^{-1}$; Table 1). Higher turnover rates in the SEC/NECC area were a result of the relatively higher bacterial production.

\section{PEDS enrichment experiment}

The enrichment incubation experiment investigated the response of bacterial populations to the addition of resources directly extracted from natural plankton assemblages. Under the minimized grazing conditions, bacterial cell numbers in both PEDS-amended and unamended samples increased with time at both stations (Fig. 5). In unamended samples, the bacterial cell increase rate was 2 times higher at the $5^{\circ} \mathrm{N}$ station (5349 cells ml ${ }^{-1} \mathrm{~h}^{-1}$ ) in the well-mixed SEC/NECC than at the nutrient-depleted $10^{\circ} \mathrm{N}$ station $\left(2923\right.$ cells ml $^{-1}$ $\mathrm{h}^{-1}$ ) in the stratified NEC area. In contrast, the increase rate in bacterial cell numbers in PEDS-amended samples was 2 times higher at the $10^{\circ} \mathrm{N}$ station $(22938$ cells $\mathrm{ml}^{-1} \mathrm{~h}^{-1}$ ) than at the $5^{\circ} \mathrm{N}$ station (12500 cells ml ${ }^{-1}$ $\mathrm{h}^{-1}$ ). The results indicated that bacterial production was more resource-limited in the highly stratified NEC area $\left(10^{\circ} \mathrm{N}\right)$ than in the well-mixed SEC/NECC area with higher chl a concentrations.

\section{Biomass structure}

The ratio of $\mathrm{BCB}$ to chl-C ranged from 0.19 to 0.96 (mean: 0.48), and increased with decreasing chl $a$ and nutrient concentrations (Fig. 6A). This general relationship between $\mathrm{BCB} / \mathrm{chl}-\mathrm{C}$ and the trophic condi-
Fig. 5. Variations in bacterial abundance in the plankton extract dissolved substrate (PEDS)-amended incubation experiment in the well-mixed SEC/ NECC area at $5^{\circ} \mathrm{N}$ and the highly stratified NEC area at $10^{\circ} \mathrm{N}$
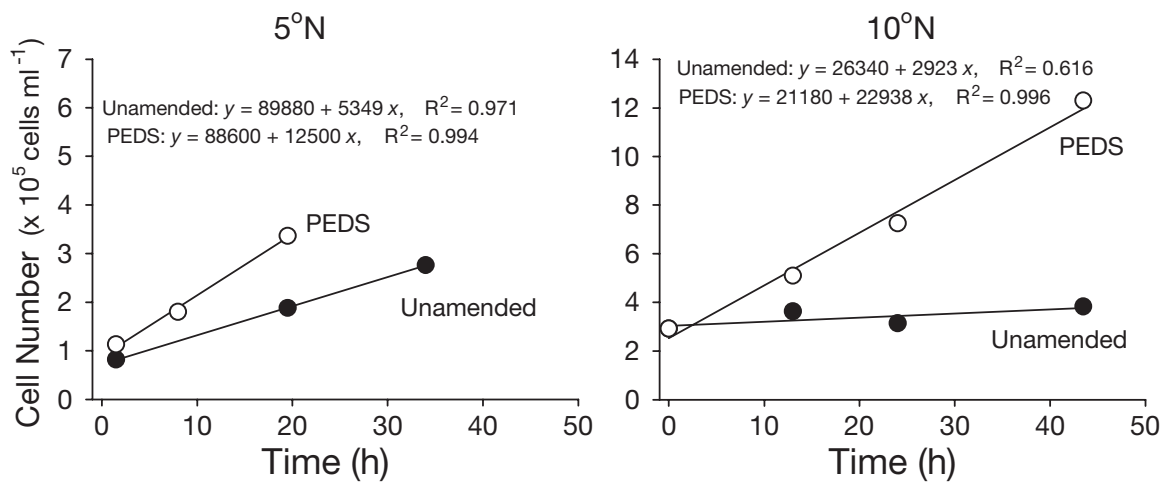

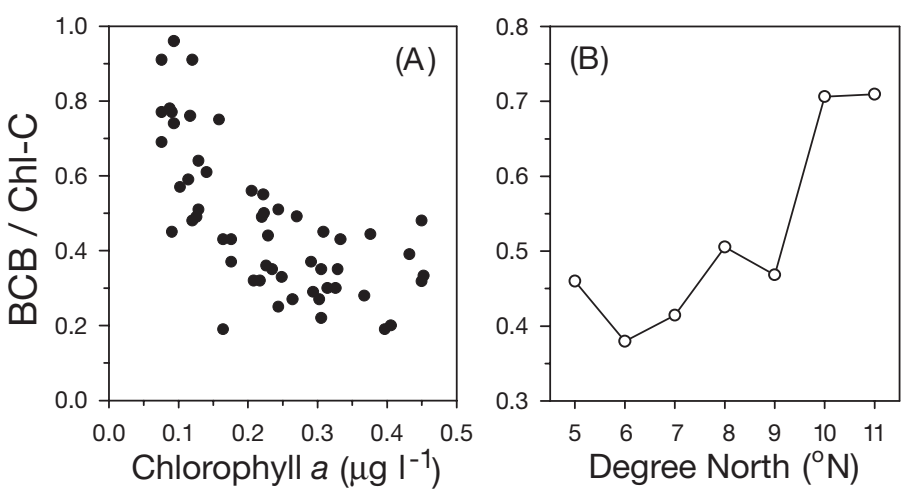

Fig. 6. Relationship between bacteria carbon biomass (BCB) and phytoplankton carbon biomass (chl-C). (A) Variations in BCB/ chl-C with chl a concentrations and (B) meridional variations in $\mathrm{BCB} / \mathrm{chl}-\mathrm{C}$

tions of the water column was clearer when the depthintegrated $\mathrm{BCB} / \mathrm{chl}-\mathrm{C}$ ratio was plotted against sampling stations (Fig. 6B). The ratio ranged from 0.38 to 0.71 (mean: 0.52), and was higher in the NEC region (mean: 0.63), with relatively high chl a and nutrient concentrations, than in the SEC/NECC area (mean: 0.42).

\section{Ingestion and grazing rates of $\mathrm{HNF}$}

The ingestion rates of HNF on bacteria were 3.89 cells $\mathrm{HNF}^{-1} \mathrm{~h}^{-1}$ at $10^{\circ} \mathrm{N}$ and 6.14 cells $\mathrm{HNF}^{-1} \mathrm{~h}^{-1}$ at $5^{\circ} \mathrm{N}$ (Table 1 ). The grazing rates of the HNF population were $1.04 \times 10^{6}$ cells $\mathrm{l}^{-1} \mathrm{~h}^{-1}$ at $5^{\circ} \mathrm{N}$ and $2.05 \times$ $10^{6}$ cells $\mathrm{l}^{-1} \mathrm{~h}^{-1}$ at $10^{\circ} \mathrm{N}$. The rates were consistently higher in the mixed SEC/NECC areas, where bacteria and HNF abundance were higher, than in the stratified NEC areas. Despite the different ingestion and

Table 2. Percentage of bacterial production removed by heterotrophic nanoflagellates (HNF) in various ocean environments

\begin{tabular}{|c|c|c|}
\hline $\begin{array}{l}\text { Study } \\
\text { area }\end{array}$ & $\begin{array}{l}\text { Bacterial production } \\
\text { ingested by HNF (\%) }\end{array}$ & Source \\
\hline Northeast equatorial & $31.4\left(5^{\circ} \mathrm{N}, 30 \mathrm{~m}\right)$ & \\
\hline Pacific & $38.4\left(10^{\circ} \mathrm{N}, 30 \mathrm{~m}\right)$ & Present study \\
\hline East Sea & $\begin{array}{c}33-98 \text { (epipelagic) } \\
22-79 \text { (mesopelagic) }\end{array}$ & Cho et al. (2000) \\
\hline Antarctic & $\begin{array}{l}3.6 \text { (avg. at polar frontal zone, } 20 \mathrm{~m} \text { ) } \\
9 \text { (avg. at intermediate water zone, } 20 \mathrm{~m} \text { ) } \\
4.1 \text { (avg. at marginal ice zone, } 20 \mathrm{~m} \text { ) }\end{array}$ & Becquevort (1997) \\
\hline Arctic & $4.5-31.7(10 \mathrm{~m})$ & Sherr et al. (1997) \\
\hline Mediterranean Sea & $\begin{array}{c}40 \text { (epipelagic, Mar) } \\
\sim 100 \text { (epipelagic, Sep) }\end{array}$ & Christaki et al. (1999) \\
\hline Mediterranean Sea & 45-87 (epipelagic, Jun) & Christaki et al. (2001) \\
\hline
\end{tabular}

grazing rates in the SEC/NECC and NEC regions, estimated HNF bacterivory appeared to be similar; HNF ingested 31.4 and $38.4 \%$ of the bacterial production at $5^{\circ} \mathrm{N}$ (SEC/NECC region) and $10^{\circ} \mathrm{N}$ (NEC region), respectively (Table 2). The removal rates in this study were higher than those reported in the Antarctic (Becquevort 1997) and Arctic regions (Sherr et al. 1997), but were within the range reported for other oligotrophic open ocean areas (Christaki et al. 1999, 2001, Cho et al. 2000). The results implied that HNF are an important trophic link between bacteria and microzooplankton in the northeast equatorial Pacific (Yang et al. 2004).

\section{DISCUSSION}

The major findings from the meso-scale spatial investigation of the physico-chemical and microbiological parameters were that: (1) the water column structures in the study area were clearly categorized as a well-mixed water mass, resulting from surface water convergence between 5 and $7^{\circ} \mathrm{N}$ (SEC/NECC area) and a highly stratified water column between 9 and $12^{\circ} \mathrm{N}$ (NEC area) (Fig. 2); (2) the well-mixed SEC/ NECC area appeared to be high in nutrients and chl $a$, whereas the strongly stratified NEC area had a relatively low trophic status, with a surface layer depleted of nitrates and chl a (Fig. 3); and consequently (3) the bacterial parameters (i.e. abundance, production, and biomass structure) and intensity of HNF grazing differed between the well-mixed SEC/NECC area and the highly stratified NEC area (Table 1, Figs. 3, 4 \& 6).

In the northeast equatorial Pacific, the range and location of each current system, which determine the scale and location of divergence and convergence, vary both temporally and spatially (Pickard \& Emery 1982). In the summer, the NECC in the northeast equatorial Pacific is normally observed from 3 to $8^{\circ} \mathrm{N}$. During the EqPac cruise, the oceanic convergent front line was observed around $3^{\circ} \mathrm{N}$ at $140^{\circ} \mathrm{W}$ (Yoder et al. 1994, Johnson 1996, Archer et al. 1997). During the present cruise $\left(131^{\circ} 30^{\prime} \mathrm{W}\right)$, despite the similar longitude to the EqPac cruise, the convergence event appeared at 5 to $6^{\circ} \mathrm{N}$. This large-scale spatial variation in hydrographic conditions is unusual, and may be associated with El Niño and La Niña events, which prevailed from 1997 to 1999 (http:// topex-www.jpl.nasa.gov). In fact, an 
exceptionally deep seasonal thermocline (approximately $100 \mathrm{~m}$ ) was observed at $10^{\circ} \mathrm{N}$ (Fig. 2), which was 30 to $40 \mathrm{~m}$ deeper than the thermocline depth during the previous 3 yr (approximately $65 \mathrm{~m}$; unpubl. data).

The difference in physical stability of water column structures between the well-mixed SEC/NECC area and the stratified NEC area (Fig. 2) influenced the distribution of chl $a$ in the surface water column (Fig. 3), and consequently determined bacterial properties (Figs. 4 \& 5). Higher bacterial biomass and production (Fig. 4), but lower increase in bacterial abundance during the PEDS enrichment incubation experiments (Fig. 5) in the SEC/NECC region also indicated that resources available for bacterial growth were more abundant than in the stratified NEC area. Chl a provides the resources that stimulate bacterial production in open ocean environments (Bjørnsen 1988, Cole et al. 1988). Protozoa also release substantial amounts of DOC, which is directly available for bacterial growth (Nagata \& Kirchman 1992, Nagata 2000).

The ratio of bacteria to phytoplankton biomass generally increased from higher (i.e. the SEC/NECC region) to lower trophic states (i.e. the $\mathrm{NEC}$ area) (Fig. 6). The lower values for BCB/chl-C in the wellmixed SEC/NECC area (Fig. 6) seem to be a result of the abundant distribution of large diatoms, resulting in higher chl-C in the convergent area (Yoder et al. 1994, J.-H. Noh unpubl. data), and abundant HNF, which effectively control the biomass of fast-growing bacterial populations (Table 1). Previous analyses of microbial biomass structure have consistently revealed that nutrient conditions largely determine the biomass structures of bacterioplankton and phytoplankton. Cho \& Azam (1990) found that the ratio of bacterial to phytoplankton biomass was $>1$ for chl a concentrations $<0.2 \mathrm{mg} \mathrm{m}^{-3}$. Herndl (1991) reported small-scale (approximately $100 \mathrm{~m}$ ) differences in biomass structures in which the ratio of bacteria to phytoplankton biomass generally increased from eutrophic to oligotrophic environments. $\mathrm{BCB}$ to $\mathrm{chl}-\mathrm{C}$ ratios plotted with the trophic (chl a) gradient in the water column (Fig. 6B) also confirmed the generalization that the biomass structures of planktonic communities vary with the trophic state of the water column. Although the absolute ratio of $\mathrm{BCB}$ to $\mathrm{chl}-\mathrm{C}$ depends on the conversion factors for the carbon content of chl a (Vedernikov et al. 1977, Li et al. 1992, Christian \& Karl 1994, Caron et al. 1995) and bacterial cells (Lee \& Fuhrman 1987 , Fukuda et al. 1998), the general relationship between $\mathrm{BCB} / \mathrm{chl}-\mathrm{C}$ and trophic status remains valid regardless of the conversion factors.

Our results also revealed that the variation in the water column structure regulating the physico-chemical conditions was responsible for regulating the inten- sity of the trophic link between bacteria and HNP. Daily HNF ingestion and grazing rates were approximately 2 times higher in the well-mixed SEC/NECC region at $5^{\circ} \mathrm{N}$ than at the highly stratified station at $10^{\circ} \mathrm{N}$ (Table 1). HNP (including heterotrophic nanoflagellates and heterotrophic dinoflagellates) are the major consumers of bacterial production in this study area (Yang et al. 2004, Table 1), and are themselves preyed upon by larger microzooplankton in the pelagic microbial food web (Sieburth et al. 1978, Sherr et al. 1986, Stoecker \& Capuzzo 1990). Therefore, the ecological implication of the higher biomass and ingestion rate of $\mathrm{HNP}$ in the SEC/NECC region is that the trophic link between bacterioplankton and heterotrophic protists is tighter in the well-mixed, highnutrient SEC/NECC region, resulting from convergence and divergence. These results are consistent with the generalization that the impact of grazing on bacterial abundance increases in productive regions where bacteria are metabolically active and fast growing (Sanders et al. 1992, Dufour \& Torréton 1996, Ducklow 2000).

The bacterial abundance in this study (Fig. 4) was represented by prokaryotic cells, because the phototrophic prokaryotes, such as Prochlorococcus, are not easily distinguished from heterotrophic bacteria in the epifluorescent microscopic enumeration of DAPIstained samples (Sieracki et al. 1995). Given that the abundance of Prochlorococcus accounts for approximately 15 to $20 \%$ of the total prokaryotic cell count in the study area (Landry et al. 1996, Landry \& Kirchman 2002, Noh et al. 2004), the heterotrophic bacterial abundance in this study may overestimate the actual heterotrophic bacterial abundance by approximately $20 \%$. Despite this uncertainty, the results of bacterial cell counts in the PEDS-amended incubation experiment (Fig. 5) and grazing experiment (Table 1) are not likely to be affected by the existence of Prochlorococcus, because the incubations for the time-course experiments were conducted in the dark. In those experiments, we also pre-filtered natural seawater at the beginning of the experiment using $0.7 \mu \mathrm{m}$ filters and GF/F filters for the HNF grazing experiment and PEDS-amended incubation experiment, respectively.

The major ecological role of heterotrophic bacteria in the marine environment depends on whether bacteria act as a trophic link between photosynthetically fixed organic carbon and higher trophic levels, i.e. HNP and metazoan microzooplankton (Azam et al. 1983, Sherr et al. 1986), or as a carbon sink respiring most of the primary production (Ducklow 1986, del Giorgio et al. 1997). Spatially variable bacterial biomass turnover rates (Table 1) and biomass structure (Fig. 6) implied that the ecological roles of bacteria in the well-mixed SEC/NECC area and the highly strati- 
fied NEC area were different. First, intense HNP grazing in the SEC/NECC region (Table 1) indicated that the bacterivores preferentially remove dividing cells (Sherr et al. 1992) and metabolically active cells (del Giorgio et al. 1996) in the high nutrient and chl a environment, and implied that actively growing bacterial carbon was transferred to higher trophic levels. Therefore, as a result of the combined effects of a sufficient resource supply, i.e. DOC from phytoplankton and protozoans (Nagata 2000), and tight grazing control on the actively growing bacterial cells, heterotrophic bacteria in the SEC/NECC area functioned as a trophic link between DOC and higher trophic levels (Table 3). On the other hand, the lower bacterial biomass turnover rates (Table 1) and the highly enhanced bacterial cell numbers in the PEDS enrichment experiment in the NEC area (Fig. 6B) suggested that bacterial production was primarily resource limited. The combined effects of the low availability of DOC and other bio-limiting nutrients in the oligotrophic open ocean create a stressful environment for bacteria, making the maintenance of active transport systems and production of extracellular enzymes difficult, and thus induce low bacterial growth efficiency (del Giorgio \& Cole 1998, 2000, Ducklow 2000). Consequently, in energy-limited environments, bacteria use much of the organic carbon in their surrounding environment for respiration (del Giorgio et al. 1997). Bacteria in the stratified NEC region were therefore likely a relative carbon sink for photosynthetically fixed organic carbon (Table 3).
In the nutrient-depleted stratified environment, relatively faster growing picoautotrophic prokaryotes, e.g. cyanobacteria or Prochlorococcus rather than heterotrophic bacteria, may be more important as a trophic link to heterotrophic nanoflagellates. For example, in the oligotrophic Mediterranean Sea, where picoautotrophic cyanobacteria are dominant primary producers, consumption of cyanobacteria by protozoa plays a pivotal role in mediating organic fluxes from primary producers to heterotrophic bacteria (Hagström et al. 1988). In turn, a substantial fraction of protozoan carbon is released through excretion and cell lysis and can be used by heterotrophic bacterioplankton. Hagström et al. (1988) further concluded that about $86 \%$ of the autotrophic production was balanced with respiration by heterotrophic bacteria and protozoa, suggesting that a significant fraction of the photosynthetically fixed carbon would be remineralized within the microbial loop, thus rendering it an energy-sink. In association with the relative significance of autotrophic picoplankton in oligotrophic environments, Hyun et al. (1998) found higher picoplanktonic chl a (65\% of total chl a) at oligotrophic stations at $10^{\circ} \mathrm{N}$ than in the diverging region $(40 \%$ of total chl a). On the same cruise, Yang et al. (2004) repeatedly observed that pico-sized $(<3 \mu \mathrm{m}) \mathrm{chl}$ a constituted $85.2 \%$ of the total $\mathrm{chl}-\mathrm{C}$ in the stratified NEC region, whereas the nano-sized (3 to $20 \mu \mathrm{m}$ ) fraction made up only $8.7 \%$. Similarly, Landry et al. (1996) found a higher fraction of Prochlorococcus in the total bacterial populations at their northern (oligotrophic) stations, between 7 and $12^{\circ} \mathrm{N}$ at a longitude of $140^{\circ} \mathrm{W}$.

Table 3. Summary of the variation in physico-chemical parameters, microbiological properties and the ecological role of heterotrophic bacteria in the SEC/NECC and NEC regions of the northeast equatorial Pacific. HNP: heterotrophic nanoprotists; BCB: bacterial carbon biomass; PEDS: plankton extract dissolved substrates

\begin{tabular}{|c|c|c|c|}
\hline & SEC/NECC region & NEC region & Evidence \\
\hline $\begin{array}{l}\text { Physico-chemical } \\
\text { properties }\end{array}$ & $\begin{array}{l}\text { Vertically well-mixed water mass } \\
\text { with a weak seasonal thermocline } \\
\rightarrow \text { Abundant nutrients in the mixed layer } \\
\rightarrow \text { High chl a concentration }\end{array}$ & $\begin{array}{l}\text { Highly stratified water column with } \\
\text { a strong seasonal thermocline } \\
\rightarrow \text { Nutrient depletion in the surface layer } \\
\rightarrow \text { Low chl a concentration }\end{array}$ & $\begin{array}{l}\text { Figs. } 2 \& 3 \\
\text { Table } 1\end{array}$ \\
\hline $\begin{array}{l}\text { Bacterial } \\
\text { parameters }\end{array}$ & $\begin{array}{l}\text { High abundance and production } \\
\rightarrow \text { High mean biomass turnover rate }\end{array}$ & $\begin{array}{l}\text { Low abundance and production } \\
\rightarrow \text { Low mean biomass turnover rate }\end{array}$ & Fig. 4, Table 1 \\
\hline $\begin{array}{l}\text { Time-course } \\
\text { experiment }\end{array}$ & $\begin{array}{l}\text { Low increase in cell numbers in the } \\
\text { PEDS-amended samples } \\
\rightarrow \text { Relatively abundant resources available } \\
\text { for supporting high bacterial growth }\end{array}$ & $\begin{array}{l}\text { High increase in cell numbers in the } \\
\text { PEDS-amended samples } \\
\rightarrow \text { Relative lack of substrate for supporting } \\
\text { bacterial growth }\end{array}$ & $\begin{array}{l}\text { Fig. 5, Table 1, } \\
\text { Yang et al. (2004) }\end{array}$ \\
\hline $\begin{array}{l}\text { HNP grazing and } \\
\text { biomass structure } \\
(\mathrm{BCB} / \mathrm{chl}-\mathrm{C})\end{array}$ & $\begin{array}{l}\text { High phytoplankton biomass and intense } \\
\text { HNP grazing on the actively growing } \\
\text { bacterial biomass } \\
\rightarrow \text { Low BCB/chl-C }\end{array}$ & $\begin{array}{l}\text { Low phytoplankton biomass and HNP } \\
\text { grazing on the slowly growing bacterial } \\
\text { biomass } \\
\rightarrow \text { High } \mathrm{BCB} / \mathrm{chl}-\mathrm{C}\end{array}$ & $\begin{array}{l}\text { Fig. 6, Table 1, } \\
\text { Hyun et al. (1998) }\end{array}$ \\
\hline $\begin{array}{l}\text { Ecological role of } \\
\text { heterotrophic } \\
\text { bacteria }\end{array}$ & $\begin{array}{l}\text { Actively growing bacterial biomass is } \\
\text { transferred to HNP (i.e. it is a significant } \\
\text { trophic link in microbial food web) }\end{array}$ & $\begin{array}{l}\text { Bacteria respire most organic carbon to } \\
\text { yield metabolic energy (i.e. they act as a } \\
\text { biogeochemical carbon sink for photosyn- } \\
\text { thetically fixed organic carbon) }\end{array}$ & \\
\hline
\end{tabular}


In conclusion, our results indicate that the bacterial abundance and production and the environmental conditions controlling bacterial parameters in the SEC/NECC region were intrinsically different from those in the stratified NEC area (Table 3). The variation in the water column structures associated with surface convergence and divergence resulting from the surface current system were mainly responsible for the observed differences in trophic conditions (i.e. nutrients and chl a) of the water column and the subsequent spatial variation in the bacterial parameters and HNF grazing. The SEC/NECC area in the equatorial convergent region is a well-established area of the open-ocean fishery (Mann \& Lazier 1991), and the variability in microbial food web processes associated with physical forcing could profoundly affect the species composition and biological productivity at higher trophic levels. Further investigation of the relationships between bacterial respiration and growth efficiency and trophic conditions is needed to provide more quantitative information on the different ecological and biogeochemical roles of heterotrophic bacteria in these 2 water columns in the northeast equatorial Pacific.

Acknowledgements. We thank the captain and crews of the RV 'Onnuri' and the research staffs of the KODOS program. We are also grateful to Dr. D. L. Kirchman and 3 anonymous reviewers for their comments, which improved an earlier version of the manuscript. This study was funded by a grant from the Korean Ministry of Maritime Affairs and Fisheries (PM99-01901), and from the Basic Research Program of KORDI (PE 92400).

\section{LITERATURE CITED}

Archer D, Aiken J, Balch W, Barber D and 13 others (1997) A meeting place of great ocean currents: shipboard observations of a convergent front at $2^{\circ} \mathrm{N}$ in the Pacific. Deep-Sea Res II 44:1827-1849

Azam F, Fenchel T, Field JG, Gray JS, Meyer-Reil LA, Thingstad F (1983) The ecological role of water-column microbes in the sea. Mar Ecol Prog Ser 10:257-263

Barange M, Pakhomov EA, Perissinotto R, Froneman PW, Verheye HM, Taunton-Clark J, Lucas MI (1998) Pelagic community structure of the subtropical convergence region south of Africa and in the mid-Atlantic ocean. Deep-Sea Res I 45:1663-1687

Becquevort S (1997) Nanoprotozooplankton in the Atlantic sector of the southern ocean during early spring: biomass and feeding activities. Deep-Sea Res II 44:355-373

Bjørnsen PK (1988) Phytoplankton exudation of organic matter: Why do healthy cells do it? Limnol Oceanogr 33: 151-154

Bradford-Grieve J, Murdoch R, James M, Oliver M, McLeod J (1998) Mesozooplankton biomass, composition, and potential grazing pressure on phytoplankton during austral winter and spring 1993 in the subtropical convergence region near New Zealand. Deep-Sea Res I 45:1709-1737

Calbet A, Landry MR (1999) Mesozooplankton influences on the microbial food web: direct and indirect trophic interactions in the oligotrophic open ocean. Limnol Oceanogr 44:1370-1380

Caron DA, Dam HG, Kremer P, Lessard EJ and 6 others (1995) The contribution of microorganisms to particulate carbon and nitrogen in surface waters of the Sargasso Sea near Bermuda. Deep-Sea Res II 42:943-972

Cherrier J, Bauer JE, Druffel ER (1996) Utilization and turnover of labile dissolved organic matter by bacterial heterotrophs in eastern North Pacific surface waters. Mar Ecol Prog Ser 139:267-279

Cho BC, Azam F (1990) Biogeochemical significance of bacterial biomass in the ocean's euphonic zone. Mar Ecol Prog Ser 63:253-259

Cho BC, Na SC, Choi DH (2000) Active ingestion of fluorescently labeled bacteria by mesopelagic heterotrophic nanoflagellates in the East Sea, Korea. Mar Ecol Prog Ser 206:23-32

Christaki U, Van Wambeke F, Dolan JR (1999) Nanoflagellates (mixotrophs, heterotrophs and autotrophs) in the oligotrophic eastern Mediterranean: standing stocks, bacterivory and relationships with bacterial production. Mar Ecol Prog Ser 181:297-307

Christaki U, Giannakourou A, Van Wambeke F, Grégori G (2001) Nanoflagellate predation on auto- and heterotrophic picoplankton in the oligotrophic Mediterranean Sea. J Plankton Res 23:1297-1310

Christian JR, Karl DM (1994) Microbial community structure at the US-Joint Global Ocean Flux Study Station ALOHA: inverse methods for estimating biochemical indicator ratios. J Geophy Res 99:14,269-14,276

Chung SP, Gardner WD, Richardson MJ, Walsh ID, Landry MR (1996) Beam attenuation and micro-organisms: spatial and temporal variations in small particles along $140^{\circ} \mathrm{W}$ during 1992 JGOFS EqPac transects. Deep-Sea Res II 43: 1205-1226

Cole JJ, Pace ML, Findlay S (1988) Bacterial production in fresh and saltwater ecosystems: a cross-system overview. Mar Ecol Prog Ser 43:1-10

del Giorgio PA, Cole JJ (1998) Bacterial growth efficiency in natural aquatic systems. Annu Rev Ecol Syst 29: 503-541

del Giorgio PA, Cole JJ (2000) Bacterial energetics and growth efficiency. In: Kirchman DL (ed) Microbial ecology of the oceans. Wiley-Liss, New York, p 289-325

del Giorgio PA, Gasol J, Vaque D, Mura P, Augusti S, Duarte CM (1996) Bacterioplankton community structure: protist control net production and the proposition of active bacteria in a coastal marine community. Limnol Oceanogr 41: 1169-1179

del Giorgio PA, Cole JJ, Cimbleris A (1997) Respiration rates in bacteria exceed phytoplankton production in unproductive aquatic systems. Nature 385:148-151

Ducklow HW (1986) Bacterial biomass in warm-core Gulf Stream ring 82-B: mesoscale distributions, temporal changes and production. Deep-Sea Res 33:1789-1812

Ducklow HW (2000) Bacterial production and biomass in the oceans. In: Kirchman DL (ed) Microbial ecology of the oceans. Wiley-Liss, New York, p 85-120

Ducklow HW, Quinby HL, Carlson CA (1995) Bacterioplankton dynamics in the equatorial Pacific during the $1992 \mathrm{El}$ Niño. Deep-Sea Res II 42:621-638

Dufour P, Torréton J-P (1996) Bottom-up and top-down control of bacterioplankton from eutrophic to oligotrophic sites in the tropical northeastern Atlantic Ocean. DeepSea Res I 43:1305-1320

Fuhrman JA, Azam F (1980) Bacterioplankton secondary pro- 
duction estimates for coastal waters of British Columbia, Antarctica, and California. Appl Environ Microbiol 39: 1085-1095

Fuhrman JA, Azam F (1982) Thymidine incorporation as a measure of heterotrophic bacterioplankton production in marine surface waters: evaluation and field results. Mar Biol 66:109-122

Fuhrman JA, Sleeter TD, Carlson CA, Proctor LM (1989) Dominance of bacterial biomass in the Sargasso Sea and its ecological implications. Mar Ecol Prog Ser 45:271-278

Fukuda R, Ogawa H, Nagata T, Koike I (1998) Direct determination of carbon and nitrogen contents of natural bacterial assemblages in marine environments. Appl Environ Microbiol 64:3352-3358

Hagström ^, Azam F, Andersson A, Wikner J, Rassoulzadegan F (1988) Microbial loop in an oligotrophic pelagic marine ecosystem: possible roles of cyanobacteria and nanoflagellates in the organic fluxes. Mar Ecol Prog Ser 49:171-178

Herndl GI (1991) Microbial biomass dynamics along a trophic gradient at the Atlantic barrier reef off Beliz (Central America). PSZN I: Mar Ecol 12:41-51

Holligan PM, Harris RP, Newell RC, Harbour DS and 5 others (1984) Vertical distribution and partitioning of organic carbon in mixed, frontal and stratified waters of the English Channel. Mar Ecol Prog Ser 14:111-127

Hyun JH, Kim KH (2003) Bacterial abundance and production during the unique spring phytoplankton bloom in the central Yellow Sea. Mar Ecol Prog Ser 252:77-88

Hyun JH, Yang EJ (2003) Freezing seawater for the long-term storage of bacterial cells for microscopic enumeration. J Microbiol 41:262-265

Hyun JH, Choi JK, Yang EJ, Kim KH (1998) Biomass and productivity of bacterioplankton related to surface water divergence in the northeast equatorial Pacific Ocean. J Microbiol 36:151-158

James MR, Hall JA (1998) Microzooplankton grazing in different water masses associated with the subtropical convergence round the south island, New Zealand. Deep-Sea Res I 45:1689-1707

Johnson ES (1996) A convergent instability wave front in the central tropical Pacific. Deep-Sea Res II 43:753-778

Karl DM (1999) A sea of change: biogeochemical variability in the North Pacific subtropical gyre. Ecosystems 2:181-214

Kiørboe T, Kaas H, Kruse B, Mohlenberg F, Tiselius P, Ærtebjerg G (1990) The structure of the pelagic food web in relation to water column structure in the Skagerrak. Mar Ecol Prog Ser 59:19-32

Kirchman DL, Suzuki Y, Garside C, Ducklow HW (1991) High turnover rates of dissolved organic carbon during a spring phytoplankton bloom. Nature 352:612-614

Kirchman DL, Rich JH, Barber RT (1995) Biomass and biomass production of heterotrophic bacteria along $140^{\circ} \mathrm{W}$ in the equatorial Pacific: effect of temperature on the microbial loop. Deep-Sea Res II 42:603-619

Landry MR, Kirchman DL (2002) Microbial community structure and viability in the tropical Pacific. Deep-Sea Res II 49:2669-2693

Landry MR, Kirshtein J, Constantinou J (1996) Abundances and distribution of picoplankton populations in the central equatorial Pacific from $12^{\circ} \mathrm{N}$ to $12^{\circ} \mathrm{S}, 140^{\circ} \mathrm{W}$. Deep-Sea Res II 43:871-890

Lee S, Fuhrman JA (1987) Relationship between biovolume and biomass of naturally derived marine bacterioplankton. Appl Environ Microbiol 53:1298-1303

Li WKW, Dickie PM, Irwin BD, Wood AM (1992) Biomass of bacteria, cyanobacteria, prochlorophytes and photosyn- thetic eukaryotes in the Sargasso Sea. Deep-Sea Res 39: 501-519

Mann KH, Lazier JRN (1991) Dynamics of marine ecosystems. Blackwell, Boston, MA

Münster U, Chróst RJ (1990) Origin, composition, and microbial utilization of dissolved organic matter. In: Overbeck J, Chróst RJ (eds) Aquatic microbial ecology: biochemical and molecular approaches. Springer-Verlag, New York, p 8-46

Murray JW, Johnson E, Garside C (1995) A US JGOFS process study in the equatorial Pacific (EqPac): introduction. Deep-Sea Res II 42:275-293

Nagata T (2000) Production mechanisms of dissolved organic matter. In: Kirchman DL (ed) Microbial ecology of the oceans. Wiley-Liss, New York, p 121-152

Nagata T, Kirchman DL (1992) Release of macromolecular organic complexes by heterotrophic marine flagellates. Mar Ecol Prog Ser 83:233-240

Noh JH, Yoo SJ, Lee MJ, Son SK, Kim WS (2004) A flowcytometric study of autotrophic picoplankton in the tropical eastern Pacific. Ocean Polar Res 26:273-286

Parsons TR, Maita Y, Lalli CM (1984) A manual of chemical and biological methods for seawater analysis. Pergamon Press, Oxford

Pickard GL, Emery WJ (1982) Descriptive physical oceanography. Pergamon Press, Oxford

Porter KG, Feig YS (1980) The use of DAPI for identifying and counting aquatic microflora. Limnol Oceanogr 25:943-948

Rich JH, Ducklow HW, Kirchman DL (1996) Concentrations and uptake of neutral monosaccharides along $140^{\circ} \mathrm{W}$ in the equatorial Pacific: contribution of glucoase to heterotrophic bacterial activity and DOM flux. Limnol Oceanogr 41:595-604

Sanders RW, Caron DA, Berninger UG (1992) Relationships between bacteria and heterotrophic nanoplankton in marine and freshwaters: an inter-ecosystem comparison. Mar Ecol Prog Ser 86:1-14

Sherr E, Sherr B (2000) Marine microbes: an overview. In: Kirchman DL (ed) Microbial ecology of the oceans. WileyLiss, New York, p 13-46

Sherr EB, Sherr BF, Paffenhöfer GA (1986) Phagotrophic protozoa as food for metazoans: a 'missing' trophic link in marine pelagic food webs? Mar Microb Food Webs 1: $61-80$

Sherr BF, Sherr EB, Fallon RD (1987) Use of monodispersed, fluorescently-labeled bacteria to estimate in situ protozoan bacterivory. Appl Environ Microbiol 53:958-965

Sherr BF, Sherr EB, Pedros-Alio C (1989) Simultaneous measurement of bacterioplankton production and protozoan bacterivory in estuarine water. Mar Ecol Prog Ser 54: 209-219

Sherr BF, Sherr EB, McDaniel J (1992) Effect of protistan grazing on the frequency of dividing cells in bacterioplankton assemblages. Appl Environ Microbiol 58: 2381-2385

Sherr EB, Sherr BF, Fessenden L (1997) Heterotrophic protists in the central Arctic Ocean. Deep-Sea Res II 44:1665-1682

Sieburth JMcN, Smectacek V, Lenz J (1978) Pelagic ecosystem structure: heterotrophic components of the plankton and their relationship to plankton size fractions. Limnol Oceanogr 23:1256-1263

Sieracki ME, Haugen EM, Cucci TL (1995) Overestimation of heterotrophic bacteria in the Sargasso Sea: direct evidence by flow and imaging cytometry. Deep-Sea Res I 42: 1399-1409

Stoecker DK, Capuzzo JM (1990) Predation on protozoa: its importance to zooplankton. J Plankton Res 12:892-908 
Strom SL, Benner R, Ziegler S, Dagg MJ (1997) Plankton grazers are a potentially important source of marine dissolved organic carbon. Limnol Oceanogr 42:1364-1374

Sundh I (1992) Biochemical composition of dissolved organic carbon derived from phytoplankton and used by heterotrophic bacteria. Appl Environ Microbiol 58:2938-2947

Vedernikov VI, Koblentz-Mishke OJ, Sukhanova IN, Karabashev GS, Fisher JK (1977) A comparison of the vertical dis-

Editorial responsibility: Jed Fuhrman,

Los Angeles, California, USA tribution of seston, chlorophyll, phytoplankton pigment luminescence in the equatorial and Peruvian regions of eastern Pacific Ocean. Pol Arch Hydrobiol 24:215-226

Yang EJ, Choi JK, Hyun JH (2004) Distribution and structure of heterotrophic protist communities in the northeast equatorial Pacific Ocean. Mar Biol 146:1-15

Yoder JA, Ackleson SG, Barber RT, Flament P, Balch WM (1994) A line in the sea. Nature 371:689-692

Submitted: March 9, 2005; Accepted: October 6, 2005

Proofs received from author(s): October 30, 2005 